\title{
Selection processes in a citrus hybrid population using RAPD markers ${ }^{(1)}$
}

\author{
Roberto Pedroso de Oliveira ${ }^{(2)}$, Carlos Ivan Aguilar-Vildoso ${ }^{(3)}$ and Marcos Antônio Machado ${ }^{(3)}$
}

\begin{abstract}
The objective of this work was to evaluate the processes of selection in a citrus hybrid population using segregation analysis of RAPD markers. The segregation of 123 RAPD markers between 'Cravo' mandarin (Citrus reticulata Blanco) and 'Pêra' sweet orange ( $C$. sinensis (L.) Osbeck) was analysed in a $\mathrm{F}_{1}$ progeny of 94 hybrids. Genetic composition, diversity, heterozygosity, differences in chromosomal structure and the presence of deleterious recessive genes are discussed based on the segregation ratios obtained. A high percentage of markers had a skeweness of the 1:1 expected segregation ratio in the $F_{1}$ population. Many markers showed a 3:1 segregation ratio in both varieties and 1:3 in 'Pêra' sweet orange, probably due to directional selection processes. The distribution analysis of the frequencies of the segregant markers in a hybrid population is a simple method which allows a better understanding of the genetics of citrus group.
\end{abstract}

Index terms: Citrus reticulata, Citrus sinensis, segregation, genetic markers.

\section{Processos de seleção em uma população de híbridos de citros usando marcadores RAPD}

\begin{abstract}
Resumo - O objetivo deste trabalho foi avaliar processos de seleção em uma população híbrida de citros, por meio de análise da segregação de marcadores RAPD. A segregação de 123 marcadores RAPD entre tangerina 'Cravo' (Citrus reticulata Blanco) e laranja 'Pêra' ( $C$. sinensis (L.) Osbeck) foi analisada em uma progênie $F_{1}$ composta por 94 híbridos. Composição genética, diversidade, heterozigosidade, diferenças estruturais dos cromossomos e presença de genes deletérios recessivos nos parentais foram discutidas com base nos tipos de segregação obtidos. Uma porcentagem elevada de marcadores com segregação distorcida em relação à proporção $1: 1$ esperada foi obtida na população $\mathrm{F}_{1}$. Muitos marcadores apresentaram segregação 3:1 em ambas as variedades e 1:3 em laranja 'Pêra' provavelmente decorrente de um processo de seleção direcional. A análise de distribuição da frequiência dos marcadores segregantes na população híbrida é um método simples que possibilita uma melhor compreensão da genética do grupo citros.
\end{abstract}

Termos para indexação: Citrus reticulata, Citrus sinensis, segregação, marcador genético.

\section{Introduction}

The genus Citrus presents mainly diploid species with a chromosome haploid number of $n=9$ (Cameron \& Frost, 1968), which easily cross among themselves

\footnotetext{
(1) Accepted for publication on September 4, 2003.

(2) Embrapa-Centro de Pesquisa Agropecuária de Clima Temperado, Caixa Postal 403, CEP 96001-970 Pelotas, RS, Brasil. Bolsista do CNPq. E-mail: rpedroso@cpact.embrapa.br

(3) Centro Apta Citros Sylvio Moreira, Caixa Postal 04, CEP 13490-970 Cordeirópolis, SP, Brasil. E-mail aguilar@centrodecitricultura.br, marcos@centrodecitricultura.br
}

producing fertile hybrids (Barrett, 1985). Besides the natural crossing, spontaneous mutations, apomixis and selection are involved in the determination of the genus variability, thus making the Citrus classification very complex (Herrero et al., 1996). Its complexity is also due to other factors such as incompatibility, high heterozygosis, sterility, depression by endogamy, and polyploidy (Gmitter Junior et al., 1996).

Since the last decade, different types of molecular markers have been used in genetic analyses of citrus with the purpose of selecting hybrids and nucellar plants (Oliveira et al., 2000), evaluating the cultivar 
genotypes (Deng et al., 1995), characterizing germplasm (Machado et al., 1996), studying phylogeny (Federici et al., 1998), constructing genetic maps (Cai et al., 1994), and mapping genes of economic interest (Gmitter Junior et al., 1996; Cristofani, 1997).

Among the molecular markers, the RAPD (Random Amplified Polymorphic DNA) technique is widely used because it is inexpensive and fast, represents the whole genome, requires a low concentration of genomic DNA and produces highly polymorphic markers (Ferreira \& Grattapaglia, 1998).

The loci analyses of molecular markers with expected or skewed Mendelian segregation for a hybrid population is an important tool for genetic studies. Several types of directional selection in the prezygotic or postzygotic stages can be detected through the segregation analyses, thus inferring the genetic causes of these processes. Studies carried out by Gmitter Junior et al. (1994) and Luro et al. (1996) showed that structural alterations in the genome of the parental species occurred during the speciation with a consequential failure in the pairing and, especially, the existence of recessive deleterious genes in the Citrus due to its highly heterozygous make-up have been the causes of the processes of selection.

The objective of this work was to study the processes of selection that occurred in a citrus hybrid population using segregation analysis of RAPD markers.

\section{Material and Methods}

\section{Plant material}

Through morphologic and RAPD markers, it was possible to select 94 zygotic seedlings obtained from the crossing between 'Cravo' mandarin (Citrus reticulata Blanco), female parental, and 'Pêra' sweet orange (C. sinensis (L.) Osbeck). The evaluated plants were transferred, under greenhouse condition, to 5-L-polyethylene bags containing a perlite-based commercial substrate.

\section{RAPD markers}

Leaf samples from 94 hybrids and from both parents were utilized for DNA extraction according to Cristofani (1997). The quantification of DNA was done in $0.8 \%$ agarose gel stained with ethidium bromide $\left(0.5 \mathrm{ng} \mathrm{mL}^{-1}\right)$, and compared to the $\lambda$-DNA standard bands.

Amplification of the samples was conducted in volumes of $13 \mu \mathrm{L}$ with $1.3 \mu \mathrm{L}$ of $10 \mathrm{X}$ buffer $(200 \mathrm{mM}$ Tris$\mathrm{HCl} \mathrm{pH} \mathrm{8.4;500} \mathrm{mM} \mathrm{KCl);} 1.54 \mathrm{mM}$ of $\mathrm{MgCl}_{2} ; 0.2 \mathrm{mM}$ of each dNTP (dATP, dCTP, dTTP, and dGTP); $15 \mathrm{ng}$ of each primer; 1.5 units of DNA Taq Polymerase; and $15 \mathrm{ng}$ of genomic DNA. The amplifications were performed in a thermocycler programmed for 36 cycles of $1 \mathrm{~min}$ at $92^{\circ} \mathrm{C}$, $1 \mathrm{~min}$ at $36^{\circ} \mathrm{C}, 2 \mathrm{~min}$ at $72^{\circ} \mathrm{C}$ and with a final extension at $72^{\circ} \mathrm{C}$ for $10 \mathrm{~min}$. Ninety seven arbitrary sequences decamer primers were utilized from the Operon Technologies Inc. kits A, AB, AT, AV, B, C, D, E, G, H, I, M, N, P, Q, R, U and $\mathrm{Y}$. These primers were selected based on the presence of at least one polymorphic band in the parents, which segregated in the progeny.

Following PCR (Polymerize Chain Reaction), aliquots of $2 \mu \mathrm{L}$ of amplification products were analyzed by electrophoresis in $1.4 \%$ agarose gels containing $5 \mu \mathrm{g} \mathrm{mL}^{-1}$ of ethidium bromide. The electrophoresis was conducted at $94 \mathrm{~V}$ for approximately 3 hours in $1 \mathrm{X}$ TAE $(0.04 \mathrm{M}$ Tris-acetate $+1 \mathrm{mM}$ EDTA). One kb DNA Ladder molecular weight standards were used.

Polymorphic bands were evaluated according to their presence or absence in the individuals from the progeny and in the parents. Only those bands that were intense, well defined and reproducible were selected.

\section{Segregation analysis}

The expected null hypothesis of Mendelian segregation $1: 1$ and the types $3: 1$ and $1: 3$ were tested for each RAPD marker using the $\chi^{2}$ analysis $(\rho<0.05, \rho<0.01$ and $\rho<0.001$, $\mathrm{DF}=1$ ) based on the segregation in the progeny.

The markers from 'Pêra' sweet orange and from 'Cravo' mandarin were distributed into classes based on the percentage of individual progeny with the RAPD band. Therefore, for each variety, data were arranged in ten intervals of classes, where each had at least one marker. The hypothesis of a normal distribution for the number of markers of the classes was evaluated through the $\chi^{2}$ analysis $(\rho<0.05, \rho<0.01$ and $\rho<0.001$, DF $=10)$, after standardizing the data using the formula $\mathrm{z}=(\mathrm{x}-\mu) / \sigma$, in which $\mathrm{z}$ was the datum of the normal standardized distribution; $\mathrm{x}$ was the mean value of each class; $\mu$ was the overall mean, and $\sigma$ was the data standard deviation. The frequency of the classes obtained was correlated to the types of segregation $1: 1,1: 3$ and $3: 1$.

\section{Results and Discussion}

A total of 123 RAPD markers for 'Pêra' sweet orange and 53 for 'Cravo' mandarin were obtained. 
They were heterozygous for one parent and recessive homozygous for the other parent.

Segregation rates with significant deviation at several levels for different species were documented when compared to the expected Mendelian segregation. This study revealed that $61 \%$ and $48 \%$ of the markers had skewed segregation in the 'Pêra' sweet orange, and $26.4 \%$ and $15.1 \%$ in the 'Cravo' mandarin at $\rho<0.05$ and $\rho<0.01$, respectively, when compared to the expected 1:1 segregation (Table 1). Deviations were found in the genus Citrus in several crossings independent of the species and the type of markers utilized (Durham et al., 1992; Cai et al., 1994; Luro et al., 1996; Cristofani, 1997; Fang \& Roose, 1999). However, since there is a high genetic similarity between 'Pêra' sweet orange and 'Cravo' mandarin (Oliveira et al., 2002), it should show a high homology of structures and functions between the parents (Jarrell et al., 1992), and a lower percentage of markers with skewed segregation.

According to Grattapaglia \& Sederoff (1994), and considering a total of 123 markers of 'Pêra' sweet orange and 53 of 'Cravo' mandarin, only six and three markers with skewed segregation were expected, respectively, when considering deviations at $\rho<0.05$ comparing to an expected 1:1 Mendelian segregation.

The number of markers with skewed segregation obtained was greater than the expected. Moreover, the distribution analyses of the frequency of the number of RAPD markers found in the hybrid population revealed that the data obtained did not show a normal distribution. Then, a significant difference was observed for the markers for 'Cravo' mandarin $\left(\chi^{2}=24.71, \rho<0.01\right)$, while a difference highly significant for the 'Pêra' sweet orange $\left(\chi^{2}=69.12, \rho<0.001\right)$. Both results suggest that there are other types of segregation besides the $1: 1$.
Even though there was an effective concentration of markers in the class corresponding to the presence of RAPD markers in $50 \%$ of the hybrids, concentration of markers in the classes corresponding to the 3:1 and 1:3 segregations also occurred (Figure 1). The $\chi^{2}$ analyses of each RAPD marker in the hybrid population revealed that $22.8 \%$ of the markers from 'Pêra' sweet orange showed 3:1 segregation and $15.4 \%$ showed $1: 3$, while $5.7 \%$ of the markers from 'Cravo' mandarin had 3:1 segregation and $0 \%$ had $1: 3$ at the level of $\rho<0.05$ (Table 1).

Segregation types 3:1 and 1:3 of RAPD markers are always expected when evaluating their distribution in a hybrid population. The source of these types of segregation can be related to the limitation of the RAPD technique based upon the amplification of the fragments of different loci when they have very close or identical molecular weights that are non-distinguishable in the gel, or still when there are duplicate genes in the genome. However, these facts do not explain the percentage values obtained for these types of segregation of the markers from both varieties, and do not explain why the frequency of the markers with 3:1 segregation was greater than that of 1:3, since the choice of the markers was randomised.

Based on these results and on the segregation levels it is possible to infer that the skewed segregation of the markers showed biological cause(s) related to the genetics of the species studied. These results also revealed that some type(s) of directional selection might have occurred in the prezygotic or postzygotic development, according to Pham \& Bougerol (1993). Moreover, the DNA markers could have influenced, positively or negatively, the selection based on the linkage, even

Table 1. Percentage of RAPD markers from 'Pêra' sweet orange (Citrus sinensis (L.) Osbeck) and 'Cravo' mandarin (C. reticulata Blanco) in relationship to the segregation type in $94 \mathrm{~F}_{1}$ hybrid progeny.

\begin{tabular}{|c|c|c|c|c|c|c|}
\hline \multirow{2}{*}{$\begin{array}{l}\text { Type of } \\
\text { segregation }\end{array}$} & \multicolumn{3}{|c|}{ 'Pêra' sweet orange (\%) } & \multicolumn{3}{|c|}{ 'Cravo' mandarin (\%) } \\
\hline & $\rho<0.05$ & $\rho<0,01$ & $\rho<0,001$ & $\rho<0,05$ & $\rho<0,01$ & $\rho<0.001$ \\
\hline $1: 1$ & 38.2 & 52.8 & 57.7 & 73.6 & 86.8 & 94.3 \\
\hline Skewed & 61.0 & 48.0 & 42.3 & 26.4 & 15.1 & 5.7 \\
\hline $3: 1$ & 22.8 & 30.9 & 35.8 & 5.7 & 9.4 & 15.1 \\
\hline $1: 3$ & 15.4 & 16.3 & 24.4 & 0.0 & 3.8 & 7.5 \\
\hline $3: 1+1: 3$ & 38.2 & 47.2 & 60.2 & 5.7 & 13.2 & 22.6 \\
\hline
\end{tabular}

${ }^{(1)}$ Data analyzed by $\chi^{2}$ test. 
though they were considered neutral (Cai et al., 1994).

Several hypotheses can be used to explain the high levels of skewed segregation obtained in the markers from both varieties. Structural alteration in the genome of the parents that occurred during speciation, such as duplications, deletions, inversions and translocations, could cause skeweness in the segregation of the markers. Even though Gmitter Junior et al. (1994) documented only a few translocations and inversions in citrus, cytogenetics analyses of the pollen grain during the pairing of meiosis of the varieties Pêra and Cravo must be conducted to allow more precise inferences. In addition, if structural differences are not observed between the parents, failure during the pairing of interspecific hybrids can occur (Futuyma, 1992).

Most of the Citrus species are highly heterozygous, and endogamy can occur during crossing, thus causing the selection of large fragments from a chromosome or even an entire
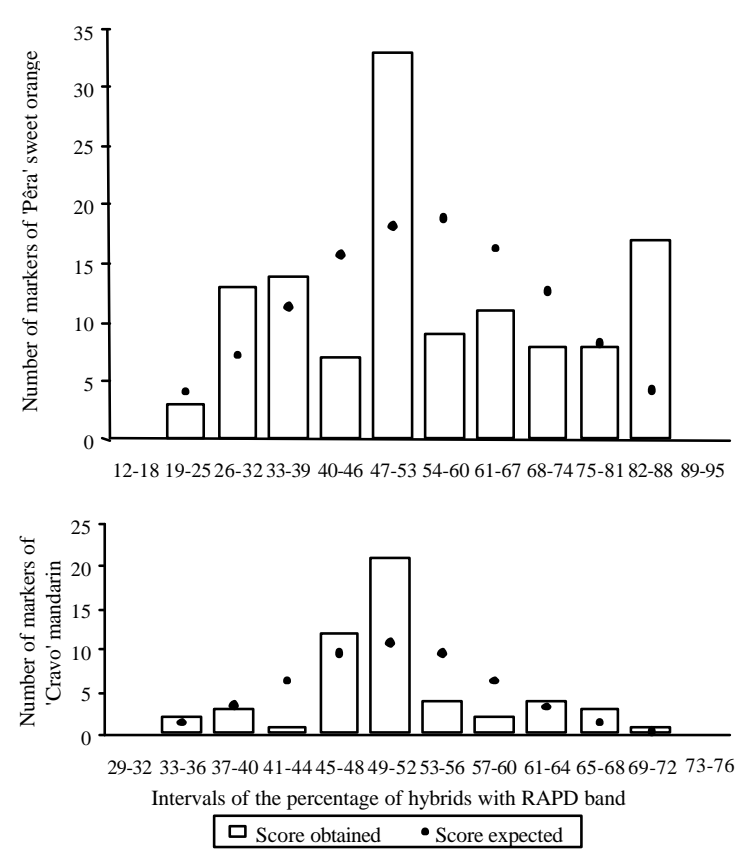

Figure 1. Distribution of the frequencies of RAPD markers from 'Pêra' sweet orange ( $C$. sinensis $(\mathrm{L}$.$) Osbeck)$ and 'Cravo' mandarin (C. reticulata Blanco) in a hybrid population. chromosome (Luro et al., 1996). Moreover, highly heterozygous structure from the parents, especially that of 'Pêra' sweet orange (Oliveira et al., 2002), shows levels close to that of hybrids obtained by man (Federici et al., 1998). This fact associated with the presumable presence of deleterious recessive genes in the heterozygous stage in the parents, and when homozygous in the hybrids, could cause a skewed segregation during crossing (Luro et al., 1996).

Although the percentage of RAPD markers with skewed segregation in 'Cravo' mandarin showed levels close to those mentioned to other species, the ones from 'Pêra' sweet orange were significant greater, i. e., 2.3 and 2.6 folds greater than those obtained from 'Cravo' mandarin at $\rho<0.05$ and $\rho<0.01$, respectively.

Several hypotheses can explain why 'Pêra' sweet orange shows greater percentage of markers with skewed segregation in relation to 'Cravo' mandarin. A high heterozygosity index of 'Pêra' sweet orange was documented by Oliveira et al. (2002). Cai et al. (1994) and Luro et al. (1996) also conducted this correlation in other crossings that involved the genus Citrus; there are differences in the homology of the chromosomes of 'Pêra' sweet orange, presupposing that $C$. sinensis is a hybrid between $C$. maxima and C. reticulata (Federici et al., 1998); the gametic selection of pollen grain from 'Pêra' sweet orange was considered to be one of the possible causes of the high levels of skewed segregation found in the markers of the male parent (Luro et al., 1996).

Overall, the distribution of the markers from 'Cravo' mandarin in the hybrid population showed expected frequencies, which were mainly of markers with $1: 1$ segregation, while the $3: 1$ and $1: 3$ segregation types were found in lower frequencies (Figure 1). In this case, the skewed segregations can be explained by the occurrence of one or more of the processes previously mentioned. However, a process of directional selection with a greater intensity occurred with the markers from 'Pêra' sweet orange. Seventeen $(13.8 \%)$ of the markers were found in the class corresponding to $82-88 \%$ of the hybrid population, which must be a real event due to the preciseness employed in the selection of the markers (Figure 1). Of special interest, $14(82.4 \%)$ of these markers formed 
a unique linkage group in the map of 'Pêra' sweet orange, which consequently might be located on the same chromosome. The entire distance between these markers in the map was only $54.8 \mathrm{cM}$, thus indicating that they are probably tightly linked.

\section{Conclusions}

1. The distribution analysis of the frequencies of the segregant markers in a hybrid population is a simple method that allows a better understanding of the genetic of citrus.

2. The distribution analysis of the frequencies of the segregant markers in a hybrid population allows the understanding of the origin and nature of markers with skewed segregation and processes of gametic or zygotic selection resulting from crossings.

\section{References}

BARRETT, H. C. Hybridization of Citrus and related genera. Fruit Varieties Journal, University Park, v. 39, p. 11-16, 1985.

CAI, Q.; GUY, C. L.; MOORE, G. A. Extension of the linkage map in Citrus using random amplified polymorphic DNA (RAPD) markers and RFLP mapping of coldacclimation-responsive loci. Theoretical and Applied Genetics, Berlin, v. 89, p. 606-614, 1994.

CAMERON, J. W.; FROST, H. B. Genetics, breeding and nucellar embryony. In: REUTHER, W.; BATCHELOR, L. D.; WEBBER, H. J. (Ed.). The citrus industry. Berkeley: University of California Press, 1968. v. 2 , p. $325-370$.

CRISTOFANI, M. Mapas de ligação de Citrus sunki Hort. ex. Tan. ePoncirus trifoliata (L.) Raf. cv. Rubidoux e localização do gene de resistência ao vírus da tristeza. 1997. 140 f. Tese (Doutorado em Genética e Melhoramento) - Escola Superior de Agricultura Luiz de Queiroz, Piracicaba, 1997.

DENG, Z. N.; GENTILE, A.; NICOLOSI, E.; DOMINA, F.; VARDI, A.; TRIBULATO, E. Identification of in vivo and in vitro lemon mutants by RAPD markers. Journal of Horticultural Sciences, Ashford Kent, v. 70, p. 117$125,1995$.

DURHAM, R. E.; LIOU, P. C.; GMITTER JUNIOR, F. G.; MOORE, G. A. Linkage of restriction fragment length polymorphisms and isozymes in Citrus. Theoretical and Applied Genetics, Berlin, v. 84, p. 39-48, 1992.

FANG, D. Q.; ROOSE, M. L. Inheritance of inter-simple sequence repeat markers in Citrus. Journal of Heredity, Washington, v. 90, p. 247-249, 1999.

FEDERICI, C. T.; FANG, D. Q.; SCORA, R. W.; ROOSE, M. L. Phylogenetic relationships within the genus Citrus (Rutaceae) and related genera as revealed by RFLP and RAPD analysis. Theoretical and Applied Genetics, Berlin, v. 96, p. 812-822, 1998.

FERREIRA, M. E.; GRATTAPAGLIA, D. Introdução ao uso de marcadores moleculares em análise genética. 3. ed. Brasília: Embrapa-Cenargen, 1998. 220 p.

FUTUYMA, D. J. Biologia evolutiva. 2. ed. Ribeirão Preto: Sociedade Brasileira de Genética/CNPq, 1992. 646 p.

GMITTER JUNIOR, F. G.; DENG, X. X.; HEARN, C. J. Cytogenetic mechanism underlying reduced fertility and seedlessness in Citrus. In: INTERNATIONAL CITRUS CONGRESS, 7., 1992, Acireale. Proceedings... Catania: International Citrus Society, 1994. v. 1, p. 125-129.

GMITTER JUNIOR, F. G.; XIAO, S. Y.; HUANG, S.; HU, X. L.; GARNSEY, S. M.; DENG, Z. A localized linkage map of the virus tristeza virus resistance gene region. Theoretical and Applied Genetics, Berlin, v. 92, p. 688$695,1996$.

GRATTAPAGLIA, D.; SEDEROFF, R. Genetic linkage maps of Eucalyptus grandis and Eucalyptus urophylla using a pseudo-testcross: mapping strategy and RAPD markers. Genetics, Oxford, v. 137, p. 1121-1137, 1994.

HERRERO, R.; ASÍNS, M. J.; PINA, J. A.; CARBONELL, E. A.; NAVARRO, L. Genetic diversity in the orange subfamily Aurantioideae - II: genetic relationships among genera and species. Theoretical and Applied Genetics, Berlin, v. 93, p. 1327-1334, 1996.

JARRELL, D. C.; ROOSE, M. L.; TRAUGH, S. N.; KUPPER, R. S. A genetic map of citrus based on the segregation of isozymes and RFLPs in an intergeneric cross. Theoretical and Applied Genetics, Berlin, v. 84, p. 4956, 1992.

LURO, F.; LAIGRET, F.; LORIEUX, M.; OLLITRAULT, P. Citrus genome mapping with molecular markers: two maps obtained by segregation analysis of progeny of one intergeneric cross. In: INTERNATIONAL CITRUS CONGRESS, 8., 1996, Sun City.Proceedings... Sun City: International Citrus Society, 1996. v. 2, p. 862-866. 
MACHADO, M. A.; COLETTA FILHO, H. D.; TARGON, M. L. P. N.; POMPEU JUNIOR, J. Genetic relationship of Mediterranean mandarins (Citrus deliciosa Tenore) using RAPD markers. Euphytica, Wageningen, v. 92, p. 321-326, 1996.

OLIVEIRA, R. P. de; CRISTOFANI, M.; AGUILARVILDOSO, C. I.; MACHADO, M. A. Diversidade genética entre híbridos de tangerina 'Cravo' e laranja 'Pêra'. Pesquisa Agropecuária Brasileira, Brasília, v. 37, n. 4, p. 479-484, abr. 2002.
OLIVEIRA, R. P. de; NOVELLI, V. M.; MACHADO, M. A. Freqüência de híbridos em cruzamento entre tangerina 'Cravo' e laranja 'Pêra': análise de marcadores morfológicos e RAPD. Pesquisa Agropecuária Brasileira, Brasília, v. 35, n. 9, p. 1895-1903, set. 2000.

PHAM, J. L.; BOUGEROL, B. Abnormal segregations in crosses between two cultivated rice species. Heredity, Washington, v. 70, p. 466-471, 1993. 